\title{
CSR in Electrification of Rural Africa
}

\author{
The Case of ABB in Tanzania
}

\author{
Niklas Egels \\ Göteborg University, Sweden
}

Multinational corporations (MNCs) are beginning to explore low-income markets in Africa in search of legitimacy and growth opportunities. This paper examines the CSR (corporate social responsibility) aspects of this trend by analysing: (a) how the processes of defining CSR develop when MNCs enter low-income markets in Africa; and (b) what the outcomes of these processes are in terms of local definitions of CSR. A framework for analysing these two research questions is developed by linking descriptive stakeholder theory to actor-network theory. Doing this contributes to stakeholder research by showing how firms actively shape their stakeholder environment, the similarities of firm-stakeholder interactions and the role of artefacts in firm-stakeholder interactions. The developed framework is illustrated in a study of an Asea Brown Boveri (ABB) rural electrification project in Tanzania.

\footnotetext{
Rural electrification

Low-income markets

CSR

- Stakeholder theory

Actor-network theory

ANT

- Tanzania

- ABB
}

Niklas Egels is a PhD student at the School of Economics and Commercial Law at Göteborg University, Sweden. His areas of research are international business and corporate social responsibility, especially in relation to multinational corporations in developing countries.

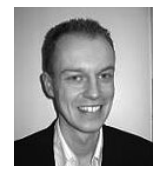

$\triangle$ Centre for Business in Society, School of Economics and Commercial Law at Göteborg University, SE-412 96 Göteborg, Sweden

Niklas.Egels@handels.gu.se

www.handels.gu.se 

MNCs have, of course, previously operated in Africa, but they have mainly aimed at either producing products for export or serving middle- or upper-class local markets. Notable examples of MNCs now exploring low-income African markets include Ericsson, Asea Brown Boveri (ABB), Tetra Pak and The Dow Chemical Company.

There has been little research into this trend in general (London and Hart 2004; Prahalad 2005) and into its CSR (corporate social responsibility) aspects in particular. Such CSR-focused research is essential, given the potential magnitude of the impacts of MNCs on African societies. There are two main ways to analyse these issues. First, we can analyse how MNCs perform with reference to previously suggested definitions of CSR (e.g. Carroll I979, I999). Second, we can start from the beginning and closely examine how an MNC's social responsibilities are in practice negotiated and defined when it enters a low-income market. The second approach is used here so as to be sensitive to the 'unique characteristics of the operational setting' (Rowley and Berman 2000: 407) and to recognise that definitions of CSR mainly developed in Europe and North America might miss some of the uniqueness of low-income African markets. Two research questions are used in analysing how local definitions of CSR are established: first, how do the processes of defining CSR develop when MNCs enter low-income markets in Africa, and, second, what are the outcomes of these processes in terms of local definitions of CSR?

In developing a framework for analysing these two questions, I make three theoretical contributions to descriptive stakeholder theory. The previous stakeholder literature provides little understanding of how firms help shape their stakeholder environment, the processes of firm-stakeholder interactions and the potentially influential role of artefacts (defined later) in firm-stakeholder interactions. I argue that a framework for analysing these factors is vital for understanding how a local definition of CSR is established. This paper presents such a theoretical framework by enriching descriptive stakeholder theory with reasoning from actor-network theory. The resulting framework is exemplified using a case study of the Swedish-Swiss multinational, ABB, and its rural electrification project, Access to Electricity, in Tanzania.

\section{Theoretical framework}

\section{Descriptive stakeholder theory}

Descriptive stakeholder theory describes the interaction between organisations and their stakeholders (Rowley 1997). Within this general theoretical approach researchers focus on both the firm's side (e.g. Hill and Jones I992; Mitchell et al. I997; Rowley I997; Driscoll and Crombie 200I; Jawahar and McLaughlin 2001; Elms et al. 2002) and the stakeholder's side of the interaction (e.g. Hill and Jones I992; Frooman I999; Rowley and Berman 2000; Friedman and Miles 2002; Rowley and Moldoveanu 2003). Analysis of previous research into descriptive stakeholder theory reveals a deficiency in three areas vital for understanding how local definitions of CSR are established. First, it is rarely discussed how firms are actively involved in choosing and creating their stakeholder environment: an implicit assumption is that a firm's stakeholder environment is a given. Second, little emphasis is placed on the firm-stakeholder interaction processes. Focus is instead on the results of these processes. The argument is that certain conditions produce certain results: for example, that the degree of firm centrality in a network is associated with different types of firm strategy (Rowley 1997), or that the 
degree of firm-stakeholder dependency is associated with different types of stakeholder strategy (Frooman I999). How these results are created, however, is not analysed in previous stakeholder literature. Third, the importance of artefacts in affecting firmstakeholder relationships is virtually ignored.

To shed light on these three unexplored areas of descriptive stakeholder theory and to outline a framework for analysing how local definitions of CSR are established, I propose the use of actor-network theory. While agency theory (Hill and Jones I992), resource dependency theory (Frooman I999; Jawahar and McLaughlin 200I), institutional theory and social network theory (Rowley 1997) have all been used to enrich descriptive stakeholder theory, actor-network theory represents a so far untapped theoretical resource.

\section{Actor-network theory}

Actor-network theory (ANT) deals with the processes of establishing facts and definitions. More specifically, the theory analyses how the processes, controversies and negotiations leading to the formulation of a definition develop (Newton 2002). ANT emphasises that the establishment of definitions affects the values endorsed in the local context (Latour i986). The definitions a firm helps to establish can thus be treated as the practical definition of CSR in a particular local context. Hence, this paper defines CSR empirically and locally, based on the interaction between the firm and its stakeholders. Such a definition is sensitive to the potentially unique conditions of low-income African markets.

The concept of translation, used in ANT research in describing the establishment of local definitions, comprises four stages (Callon i986a, I986b):

I. In the problematisation stage a focal actor formulates the definition of CSR that this actor wants to see adopted. The focal actor does this by proposing roles for many other actors, and by proposing links between these roles. The aim is to define these roles and links so that the focal actor becomes indispensable.

2. In the following intressement stage, the focal actor attempts via a series of processes to lock other actors into the defined roles. To achieve this intressement, the focal actor attempts to draw on multiple artefacts and other actors in order to persuade, seduce or force the actors to accept the problematisation.

3. The result of successful intressement is enrolment, meaning that the other actors accept their assigned roles. If not, the enrolment has failed and the focal actor returns to the problematisation stage.

4. The focal actor attempts to mobilise all the actors involved in the problematisation to play their assigned roles. If successful, the mobilisation stage completes the process of translation and a network of actors is formed around a certain definition of CSR.

This actor network is initially fragile, and is particularly susceptible to mutiny within its ranks. Enrolment of actors is often done by enrolling spokespersons for groups of actors. Mutiny occurs if these spokespersons cannot persuade the actors they supposedly represent to assume the roles defined in the problematisation stage. The end result of several successful translation processes is that a local definition of CSR is established, solidified and stabilised with agreement between key actors emerging.

A theoretical framework can now be derived for analysing the two research questions. First, ANT shows that the processes comprising translation can be used to study how the processes of defining CSR develop in the local context. Second, ANT shows that the 
full range of outcomes of these translation processes can be treated as the definition of CSR in the local context. The link to descriptive stakeholder theory and the firmstakeholder relationship also emerges, with the processes of defining CSR taking place between the firm and its stakeholders. According to ANT, however, besides the firm and its stakeholders, artefacts also influence these processes. The argument is that artefacts incorporate values and structures that enforce certain definitions of CSR (Callon I99I). Therefore, if one artefact is replaced with another, this can be expected to influence which definition of CSR is enforced. The three main types of artefact are: technical devices and equipment, texts and animals (cf. Law i986). ${ }^{7}$ After the case study, I will return to how this framework fills the three gaps I identified in previous stakeholder research.

\section{Methodology}

Research based on ANT tends to use a qualitative methodology, collecting data mainly from interviews, observations and written sources (e.g. Callon I986a, I986b). This qualitative approach is in line with the methods suggested for analysing the emergence of definitions in local contexts (Weick I996), and for analysing MNCs in low-income markets in developing countries (London and Hart 2004). Like previous ANT research, this paper builds on data collected from interviews, observation and written sources. Thirty-four interviews were held with representatives of ABB and its various business stakeholders (e.g. Ericsson and Tetra Pak), non-governmental stakeholders (e.g. UNDP, World Bank, WWF and unions), governmental stakeholders (e.g. Swedish and Tanzanian government agencies) and village stakeholders. Each representative involved in the studied project in Tanzania was interviewed two to five times for an average of one and a half hours per interview. Given the limited written sources available at the village level, data here were mainly collected by means of observations and interviews. In contrast, more written information was used at the international level.

\section{ABB's 'Access to Electricity' project}

\section{Initiating 'Access to Electricity'}

In 2002, ABB approached the WWF (World Wide Fund for Nature) in the hope of forming a partnership for rural electrification. ABB's idea was to direct some of the funds it had donated to an existing collaboration to a rural electrification project in Tanzania. The choice of rural sub-Saharan Africa was related to the low level of electrification in this region. Of the I. 6 billion people lacking access to electricity around the globe, 500 million live in sub-Saharan Africa, making it perhaps the region most in need of electricity (IEA 2002). Additionally, 80\% of those without electricity in the region live in rural areas, and $92 \%$ of this rural population lack electricity (IEA 2002). WWF International embraced the idea and assumed the responsibility for identifying a suitable Tanzanian village for a pilot project. WWF Tanzania (WWF TZ) recommended the small, remote village of Ngarambe, located just outside the Selous Game Reserve (one of the

1 To simplify, I use 'artefacts' as synonymous with the ANT concept 'non-human actors'. This leads to the inclusion of animals in 'artefacts' and to a broader definition of the concept compared with its conventional use. 
world's most important areas for elephant and rhino populations). WWF TZ had worked with Ngarambe since the mid-I990s to increase the villagers' involvement in wildlife conservation and to strengthen democratic institutions, increase transparency and decrease gender inequalities. After choosing Ngarambe as a pilot project site, ABB launched its 'Access to Electricity' project at the 2002 World Summit in Johannesburg. $\mathrm{ABB}$ presented the 'Access to Electricity' project as its attempt to build a long-term profitable rural electrification business and the Ngarambe project as its way to gain the necessary experiences for this.

\section{A controversial power source}

After choosing the village, ABB and WWF turned to the choice of power source. For various reasons, wind, water and grid extension were rather quickly ruled out as main power sources, leaving diesel and solar cells as options. While recognising that diesel was environmentally unsustainable, ABB TZ and WWF TZ suggested that it was the only viable alternative given the project's budget. ABB's international 'Access to Electricity' manager, and in particular, the project manager at WWF International, were dissatisfied with this solution. Eventually, ABB allowed WWF to make the final decision on power source.

The stakes increased as WWF International departments started internally criticising the potential use of diesel with reference to carbon dioxide $\left(\mathrm{CO}_{2}\right)$ emissions, claiming that such a project would damage WWF's credibility. The WWF project manager had in essence three choices: endorse diesel, abandon the project, or renegotiate the project budget in order to broaden the range of viable options. Knowing that $\mathrm{ABB}$ was in the aftermath of financial crisis, the WWF manager deemed a budget increase highly unlikely. He decided, after lengthy discussion with WWF TZ, to proceed with diesel rather than to terminate the project. However, he insisted on using the most environmentally friendly diesel engine on the market and on conducting a feasibility study in the second phase of the project concerning the use of wind power as backup. The ABB manager agreed to divert funds from the budget to accommodate these suggestions. The choice of diesel has since then been questioned by several stakeholders at the international level, some at the Tanzanian level and hardly any at the village level.

\section{Disagreement about the desirability of electricity}

At the international level, ABB's stakeholders seemed to view rural electrification as highly desirable. The UN Water, Energy, Health, Agriculture and Biodiversity Initiative (WEHAB), for example, identified provision of electricity as one of the five most prioritised areas for development. Similar statements are found in the World Energy Council's recent report on the future of African energy (WEC 2003) and in the International Energy Agency's reports (e.g. IEA 2002). The World Bank, in collaboration with international donor agencies, is also scaling up its rural electrification efforts. To this end, its Rural Electrification Funds (REFs) have been or are being created in, for example, Tanzania, Uganda and Senegal. These funds will centralise and co-ordinate most international funding activities and provide subsidies for part of the initial investment (but not the operational costs) for rural electrical systems.

In Ngarambe, however, the villagers were rather sceptical, some initially not wanting electricity in their houses. This seemed partly related to ignorance of the benefits of electricity, and partly to a mistrust of companies in general and, in this case, of ABB. Additionally, some villagers' beliefs strongly opposed the provision of electricity. This was particularly evident with the village's traditional medicine man, who has yet to allow any $\mathrm{ABB}$ employee to set foot in his house, let alone install electricity. 
To reduce costs, ABB TZ initially envisioned installing the distribution cables between the generator and the houses above ground. WWF TZ, however, rejected this option on the grounds that elephants, often present in and around Ngarambe, might topple the poles and get electrocuted. ABB accepted this reasoning and decided to incur the additional cost of burying cables underground. $\mathrm{ABB}$, WWF and the village government all agreed that the villagers should dig the trenches necessary for this.

Several weeks later when it came to digging the trenches, the villagers refused to do so without financial reimbursement. At this time the only project participants in the village were two ABB technicians assigned to install the distribution cables. These technicians basically had three alternatives: do nothing and delay the project, give the villagers whatever money they had, or contact WWF TZ and ABB TZ. The only way to contact WWF and $A B B$ was via a radio in a WWF camp $8 \mathrm{~km}$ away. With no car in the village, the technicians started walking to this camp on a road surrounded by head-high vegetation in an area with fairly dense populations of lions, rhinos and elephants. Upon spotting some lions down the road, the technicians decided to turn back and instead unofficially give money to some villagers for digging trenches.

\section{Training village technicians}

Since the villagers would be taking over operation of the electrical system, ABB agreed to provide necessary technical training for two villagers. The village government initially selected two candidates they claimed were best skilled for the jobs. After two weeks of training, however, the ABB team was displeased with their performance. For example, there were complaints that one of the trainees, a devout Muslim, left without notice for prayers five times a day. The team felt that in an emergency the trainee would choose to go to the mosque over repairing the electricity system, potentially jeopardising the electricity system or other villagers.

After discussion with the village government, ABB received permission to train four additional villagers. When training these, it became evident that the two initially trained villagers had been selected for tribal and family reasons, rather than for technical competence. One of the new trainees (referred to as the 'handyman') performed especially well, and the ABB team wanted to promote him to head village technician. This, however, caused serious controversy among many villagers, since the handyman was not originally from the village, was Christian (while almost all other villagers were Muslim) and had not yet been granted permanent village residency. The ABB team argued that the handyman's technical know-how was essential for the long-term functioning of the system, and that it was in the interests of the villagers to appoint him. Additionally, the team argued that tribe, religion and personal connections ('know-who') should not be decisive in recruitment. Eventually the handyman was appointed head technician. He is now more respected, trusted and accepted in the village and has also been granted permanent residency.

\section{The future of Ngarambe and 'Access to Electricity'}

ABB adopted a business model in Ngarambe similar to that proposed by the Rural Electrification Funds (REFs); that is, the villagers themselves should finance the longterm operation and maintenance of the electrical system. This financing is probably the greatest challenge for the Ngarambe village. While diesel was an attractive power source due to its low initial investment, its operational costs are high. ABB and WWF, however, seem to be supporting the village both financially and technically to such an extent that 
Ngarambe's electricity supply is likely to be secure. It is, however, unclear whether ABB has developed a business model in which villagers can financially support the system's operation and maintenance themselves. Finding such a business model is necessary now that ABB is attempting to obtain REF subsidies in order to transform its not-forprofit R\&D project in Ngarambe to several large-scale commercial projects in Tanzania, Senegal and Uganda.

\section{Establishing a local definition of CSR}

\section{How did the processes of defining CSR develop?}

I have suggested above that the processes involved in defining CSR can all be regarded as developing similarly, even though the results of the processes differ widely. The case illustrates this well. In all the described situations $A B B$ actively participated in proposing roles for the various actors (problematisation). For example, ABB proposed that WWF should help by identifying a suitable village and choosing a power source within the assigned budget and that villagers should want electricity, help digging trenches, and help selecting technician trainees. More indirectly, ABB also defined roles for other actors and artefacts: for example, lions were expected not to threaten $A B B$ employees and elephants not to interfere with the electrical lines. Even though ABB tried to persuade the actors to accept its problematisations (intressement), some refused. For example, the traditional medicine man and WWF (concerning above-ground cables) defined their roles differently, sending $A B B$ back to the problematisation stage. ABB then returned with revised roles: no electricity for the traditional medicine man and underground cables, and the persuasion of involved actors started once again. As expected, ABB employed artefacts in the form of texts and technical devices to increase the odds of successful persuasion. For example, ABB used the installed and working electricity system and written testimonies from satisfied villagers in its efforts to enrol the traditional medicine man. Enrolment and mobilisation eventually also occurred to the extent that a functional electricity system was put in place, but there were clear cases of mutiny along the way: for example, villagers refused to dig trenches without compensation and village technicians were selected based on who rather than what they knew.

Translation processes can be observed in all the analysed situations of how CSR was defined locally. However, what can be said of the instances when these processes were successful from ABB's perspective? Three main patterns are evident in the data. First, translation failed and mutiny occurred when ABB enrolled a 'spokesperson' that later was betrayed by the actors $A B B$ believed them to represent: for example, when the village government was enrolled to represent the villagers concerning digging trenches. Second, translation failed when ABB mistakenly perceived that enrolment had occurred when in fact it had not: for example, when ABB believed that the two most technically skilled technicians had been selected. Third, the likelihood of successful translation increased when $\mathrm{ABB}$ increased the number of artefacts in the network incorporating their values: for example, the likelihood that villagers would accept ABB's chosen technicians increased when a diesel system was in place that villagers could see occasionally breaking down, needing repairs and being difficult to maintain. If solar cells, which are easier to install and maintain than a diesel engine, had instead been chosen, the villagers might not have accepted the replacement technicians, as the originally assigned technicians would have been seen as 'good enough'. I will expand these observations into implications for MNCs in the concluding section. 
With an understanding of how the processes of defining CSR developed, attention can shift to the outcomes of these processes. In other words, how was CSR defined when an MNC entered a low-income Tanzanian market? Table I summarises ABB's and its most influential stakeholders' positions in the case's key conflict situations. The table also outlines the final outcome of these conflicts and provides examples of which values were enforced and which were neglected because of how CSR was actually defined in the case.

As seen in the table, several interesting prioritisations were made in the case: for example, the prioritisation of protecting wildlife by burying cables over electrification of additional houses, of unofficial payments over encounters with lions, of know-how over 'know-who' in recruitment, of proceeding with the project over $\mathrm{CO}_{2}$ emissions, of minimising generator $\mathrm{CO}_{2}$ emissions over the electrification of additional houses, and the prioritisation of villagers capable of financing system operation over those who could not. The general pattern emerging in Table $\mathrm{I}$ is that the local definition of CSR ended up somewhere between what $\mathrm{ABB}$ attempted to enforce and what its stakeholders demanded. ABB was unable to force its hoped-for CSR definition on the village, nor did it simply adopt the definition proposed by the villagers and other stakeholders. Rather there was the joint formulation of a local definition of CSR through myriad translation processes. ${ }^{2}$ From this it is evident that it does matter who the stakeholders participating in the translation processes are for the way in which CSR will be locally defined; that is, it matters how MNCs shape their stakeholder environments.

\section{Filling the three gaps in descriptive stakeholder theory}

After analysing how the process of establishing a definition of CSR develops and what its outcome is, it is possible to return to the question of how the developed theoretical framework fills in the three gaps I identified in previous descriptive stakeholder research. First, in terms of firms actively shaping their stakeholder environment, it is clear that it was no coincidence that WWF TZ and the Ngarambe villagers became important stakeholders of ABB. ABB actively chose to enrol WWF and to enter Tanzania, and through translation processes was active in determining who would become its stakeholders. Acknowledging this active MNC role is vital in gaining an understanding of how CSR is defined, since, as shown above, the local CSR definition greatly depends on what stakeholders are involved in the negotiation processes. Second, in terms of firm-stakeholder processes, the case shows that the translation processes reveal the similarities of firm-stakeholder interactions leading to the different results on which previous research has focused. Third, in terms of the importance of artefacts, the case findings show that, for example, the diesel engine and the lions threatening the ABB technicians influenced the outcome of the firm-stakeholder interactions. If it had been solar cells rather than a diesel engine or horses rather than lions, the outcome in terms of unofficial payments to villagers and the recruitment of village technicians might have been very different.

2 It is worth noting that ABB's hoped-for CSR definition in Ngarambe resembled the proposed CSR definition in ABB's international policies. However, the empirical data provide no clear explanation for this resemblance so it will not be further discussed in the paper. 


\begin{tabular}{|c|c|c|c|c|c|c|c|}
\hline 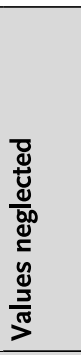 & 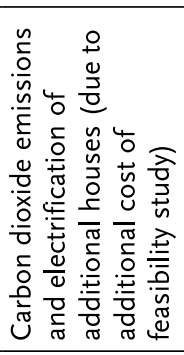 & 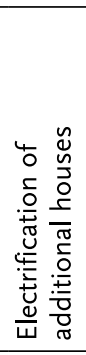 & 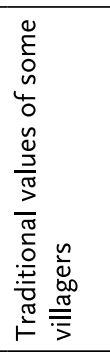 & 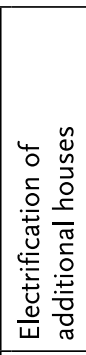 & 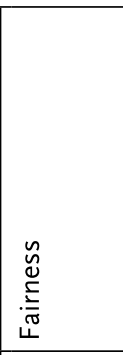 & 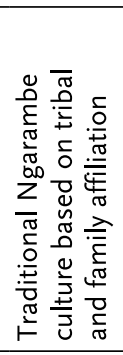 & 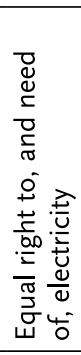 \\
\hline 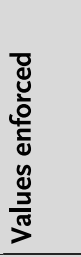 & 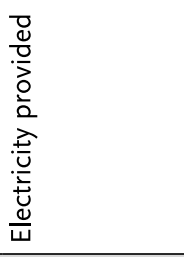 & 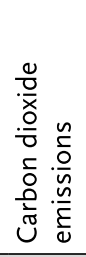 & 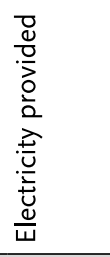 & 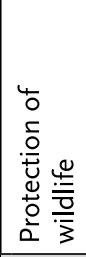 & 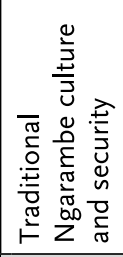 & 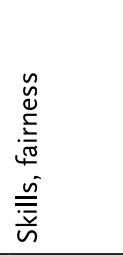 & 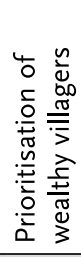 \\
\hline 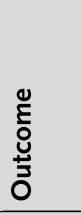 & 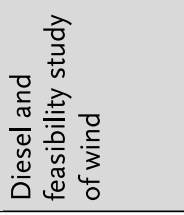 & 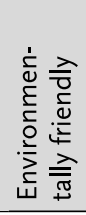 & 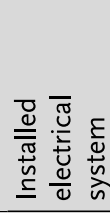 & \begin{tabular}{|l} 
\\
$\frac{0}{3}$ \\
0 \\
0 \\
00 \\
3 \\
0 \\
0 \\
0 \\
\end{tabular} & 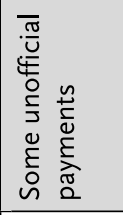 & $\begin{array}{l}3 \\
0 \\
\frac{1}{1} \\
\dot{3} \\
0 \\
\frac{1}{1} \\
\end{array}$ & 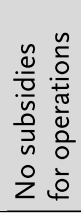 \\
\hline 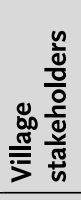 & 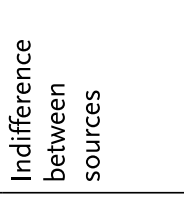 & 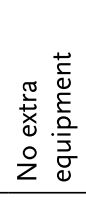 & 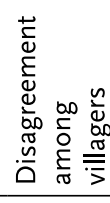 & 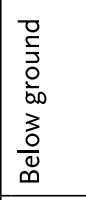 & 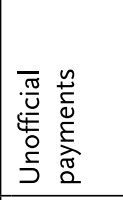 & $\begin{array}{l}\text { o } \\
\frac{1}{3} \\
\frac{1}{3} \\
0 \\
\frac{1}{2}\end{array}$ & 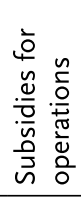 \\
\hline 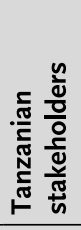 & 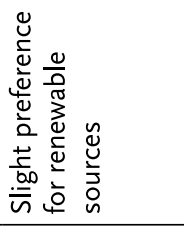 & 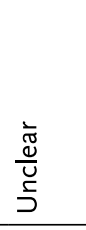 & 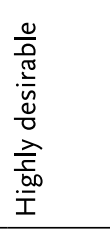 & 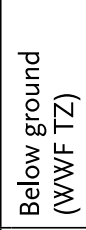 & 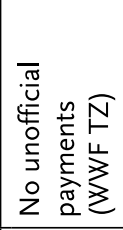 & $\begin{array}{l}3 \\
0 \\
\frac{1}{1} \\
\vdots \\
0 \\
\frac{1}{\Sigma} \\
\end{array}$ & 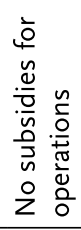 \\
\hline 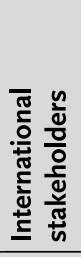 & 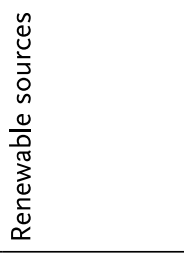 & 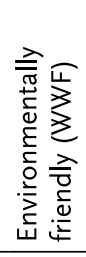 & 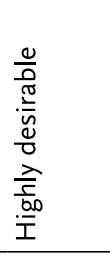 & 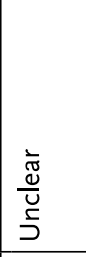 & 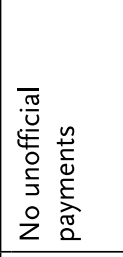 & $\begin{array}{l}3 \\
0 \\
\frac{0}{1} \\
3 \\
0 \\
\frac{1}{1} \\
\end{array}$ & 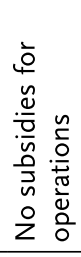 \\
\hline$\stackrel{\infty}{\stackrel{\infty}{<}}$ & 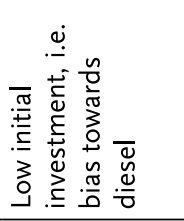 & 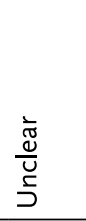 & $\begin{array}{l}\frac{0}{0} \\
\frac{\pi}{5} \\
\frac{0}{0} \\
0 \\
\frac{\lambda}{\overline{0}} \\
\frac{0.00}{1}\end{array}$ & $\begin{array}{l}0 \\
\frac{0}{5} \\
0 \\
0 \\
00 \\
0 \\
0 \\
0 \\
\frac{0}{4}\end{array}$ & 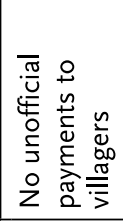 & $\begin{array}{l}3 \\
0 \\
\frac{1}{1} \\
\vdots \\
0 \\
\frac{1}{2}\end{array}$ & 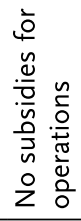 \\
\hline$\stackrel{\underline{\vec{\nu}}}{\underline{\underline{\mu}}}$ & 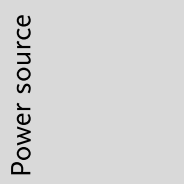 & 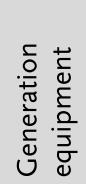 & 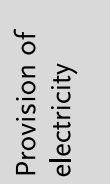 & 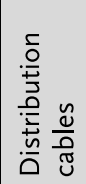 & 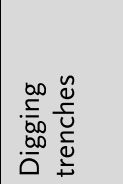 & 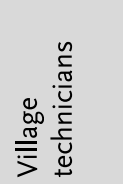 & 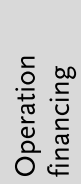 \\
\hline
\end{tabular}

Table 1 ABB'S AND ITS STAKEHOLDERS' POSITIONS 
First, managers need to be careful when identifying spokespersons for local actors, since mutiny may easily occur if the spokespersons are not actually respected. Related to this, managers also need to develop sufficient understanding of the local culture to grasp whether an actor they are attempting to enrol is deceiving them. To overcome these difficulties, I propose that MNCs should partner with organisations having strong local presence. In practice, this would often mean partnering with non-governmental organisations when entering low-income African markets.

Second, managers need to find a way to align the conflicting international and local stakeholder demands. I propose that this is most effectively done by carefully choosing what local markets to enter and with whom to partner; that is, by carefully choosing one's stakeholders. For example, WWF's previous work with Ngarambe regarding building democratic institutions, gender equality and increased transparency made it easier for ABB to achieve a local definition of CSR acceptable to both international and local stakeholders. WWF had in a sense already done much of the alignment work for ABB. Finally, to ensure that the values that MNCs want to see implemented are indeed established, managers should introduce numerous supporting artefacts (that incorporate the aspired values), such as certain technical devices and corporate codes of conduct.

\section{References}

Callon, M. (I986a) 'Some Elements of a Sociology of Translation: Domestication of the Scallops and the Fishermen of St Brieuc Bay', in J. Law (ed.), Power, Action and Belief (London: Routledge \& Kegan Paul): I96-233.

- (I986b) 'The Sociology of an Actor-Network: The Case of the Electric Vehicle', in M. Callon, B. Latour and A. Rip (eds.), Mapping the Dynamics of Science and Technology (London: Macmillan): I934 .

_ (I99I) 'Techno-economic Networks and Irreversibility’, in J. Law (ed.), A Sociology of Monsters: Essays on Power, Technology and Domination (London/New York: Routledge): I32-6I.

Carroll, A.B. (I979) 'A Three-Dimensional Conceptual Model of Corporate Performance', Academy of Management Review 4.4: 497-505.

_ (1999) 'Corporate Social Responsibility: Evolution of a Definitional Construct', Business and Society 38.3: 268-95.

Driscoll, C., and A. Crombie (200I) 'Stakeholder Legitimacy Management and the Qualified Good Neighbor: The Case of Nova Nada and JDI', Business and Society 40.4: 442-7I.

Elms, H., S. Berman and A.C. Wicks (2002) 'Ethics and Incentives: An Evaluation and Development of Stakeholder Theory in the Health Care Industry', Business Ethics Quarterly I2.4: 413-32.

Friedman, A., and S. Miles (2002) 'Developing Stakeholder Theory', Journal of Management Studies 39.I: I-2I.

Frooman, J. (I999) 'Stakeholder Influence Strategies', Academy of Management Review 24.2: I9I-205.

Hill, C., and T.M. Jones (I992) 'Stakeholder-Agency Theory', Journal of Management Studies 29.2: I3I54 .

IEA (International Energy Agency) (2002) World Energy Outlook 2002 (Paris: OECD).

Jawahar, I., and G. McLaughlin (200I) 'Toward a Descriptive Stakeholder Theory: An Organizational Life Cycle Approach', Academy of Management Review 26.3: 397-4I4.

Latour, B. (I986) 'The Powers of Association', in J. Law (ed.), Power, Action and Belief (London: Routledge \& Kegan Paul): 264-80.

Law, J. (I986) 'On the Methods of Long-Distance Control: Vessels, Navigation and the Portuguese Route to India', in J. Law (ed.), Power, Action and Belief (London: Routledge \& Kegan Paul): 234-63.

London, T., and S.L. Hart (2004) 'Reinventing Strategies for Emerging Markets: Beyond the Transnational Model', Journal of International Business Studies 35.5: 350-70.

Mitchell, R., B. Agle and D. Wood (I997) 'Toward a Theory of Stakeholder Identification and Salience: Defining the Principle of Who and What Really Counts', Academy of Management Review 22.4: 85386. 
Newton, T.J. (2002) 'Creating the New Ecological Order? Elias and Actor-Network Theory', Academy of Management Review 27.4: 523-40.

Prahalad, C.K. (2005) The Fortune of the Bottom of the Pyramid (Upper Saddle River, NJ: Wharton School Publishing).

Rowley, T. (I997) 'Moving Beyond Dyadic Ties: A Network Theory of Stakeholder Influences', Academy of Management Review 22.4: 887-910.

_ and S. Berman (2000) 'A Brand New Brand of Corporate Social Performance', Business and Society 39.4: 397-4I8.

—_ and M. Moldoveanu (2003) 'When Will Stakeholder Groups Act? An Interest- and Identity-Based Model of Stakeholder Group Mobilization', Academy of Management Review 28.2: 204-I9.

WEC (World Energy Council) (2003) The Future of African Energy (London: First Magazine and World Energy Council).

Weick, K.E. (I996) 'Drop Your Tools: Allegory for Organizational Studies', Administrative Science Quarterly 4I.2: 30I-I3. 